\title{
Angiosperm flora used by meliponine guilds (Apidae, Meliponina) occurring at rainforest edges in the state of Ceará, Brazil
}

\author{
LUIZ W. LIMA-VERDE ${ }^{1}$, MARIA I.B. LOIOLA ${ }^{1}$ and BRENO M. FREITAS ${ }^{2}$ \\ ${ }^{1}$ Universidade Federal do Ceará, Departamento de Biologia, Bloco 906, \\ Av. Humberto Monte, s/n, Campus do Pici, 60455-760 Fortaleza, CE, Brasil \\ ${ }^{2}$ Universidade Federal do Ceará, Departamento de Zootecnia, Bloco 808, \\ Av. Humberto Monte, s/n, Campus do Pici, 60021-970 Fortaleza, CE, Brasil
}

Manuscript received on February 22, 2013; accepted for publication on January 30, 2014

\begin{abstract}
Information about the use of floristic resources of the immediate edges of ombrophilous forest (Atlantic rainforest) fragments by stingless bees is not readily available in the scientific literature. Considering the importance of these plant species for local guilds of stingless bees, this study aimed to identify and characterize the flora of the immediate borders of four Atlantic rainforest fragments situated in Baturité massif, state of Ceará, used as food resource by stingless bees. We studied the growth-form of the plants, the floristic similarity between edges and the effect of rainfall on the flowering, and suggested simple techniques for handling these areas. We compiled a total of 82 plant species with a predominance of tree and shrub form. There were different floristic richness between areas and rainfall had differentiated influence on flowering, according to the edge. We concluded that the florist components of the studied edges are relevant to the stingless bee guilds, but alternative management practices are needed to conserve both plant and bee species.
\end{abstract}

Key words: deciduous forest, floristics, fragmented habitat, stingless bee, trophic resource.

\section{INTRODUCTION}

Over the past 40 years, knowledge of the floristic resources used by Brazilian native bees has been produced through systematic surveys of the bee fauna in several ecosystems. However, these studies have mostly been made in the Southeast and Southern regions, lacking information from other parts of the country (Freitas et al. 2009).

Among studies that report on food resources used by bees, including meliponines, we point out Cure et al. (1992), Souza et al. (1994), FariaMucci et al. (2003), Gonçalves and Melo (2005), in southeastern and southern Brazil; and more

Correspondence to: Breno Magalhães Freitas

E-mail: freitas@ufc.br recently Viana et al. (1997), Ramalho and Silva (2002), Locatelli et al. (2004), Milet-Pinheiro and Schlindwein (2008), Monteiro and Ramalho (2010), in northeastern Brazil.

Most of these studies were carried out in forest fragments usually associated with long historical disturbances (Viana and Pinheiro 1998, Cerqueira et al. 2003). The peripheral margins (edges) of these forest fragments suffer abrupt changes that affect local dynamics including gene flow among populations (Bierregaard et al. 1992, Viana et al. 1992, Murcia 1995, Schneider et al. 2003).

Natural or accidental occupation by native plant species, as well as those of broad geographic distribution, is quite common at such forest edges. 
This process, in general, is directly linked to the degree of matrix permeability (Cane 2001, Scariot et al. 2003, Ewers and Didham 2006). According to López-Barrera (2004), these types of low vegetation, composed mainly by shrubs and grasses have several degrees of permeability, ranging from abrupt to gradual. The latter allows, more intensively, a return of several groups of animals to this matrix range. Maciel et al. (2011) describe these areas as places where several species can establish, mainly herbs and shrubs requiring high luminosity and that present high capacity of vegetative regeneration and seed dispersal.

Studies on the phenological aspects of the flora found in forest fragments in Brazil have shown that the periodicity of the phenophases are more clearly established in environments where the weather seasonality is well defined (Morellato et al. 1989, 1990, Morellato and Leitão-Filho 1990, Talora and Morellato 2000). In such a situation, blooming periods generally depend upon the alternation of seasons; and the temporal levels of humidity are the main drivers to define these blooming periods.

Despite the lack of studies specifically on the role of forest edge flora to the stingless bees foraging resources, some studies made in Brazil with native grasslands (Gonçalves and Melo 2005, Gonçalves et al. 2009) and rainforest fragments (Antonini et al. 2003) showed a positive relationship between the surrounding flora and stingless bees, mainly those species less demanding for food resources. There is a need for more studies in order to understand the stingless bees' foraging performance in the forest edges.

To investigate this issue we conducted a floristic survey in the immediate edges of four forest fragments located in the Baturite massif in order to: i) characterize and record, the growthform of the plant species supplying food resources for stingless bees, in order to know the structure of this community botany; ii) identify floristic similarities among the studied areas to check for differences in the richness of the flora of each area; iii) record the influence of rainfall on the number of species in bloom, to get an idea of the food supply throughout the year; iv) suggest simple management measures for these edge areas in order to ensure the preservation of plant and bee species.

\section{MATERIALS AND METHODS}

STUDY AREA

The study was carried out in the Baturite massif, geographic coordinates $4^{\circ}-4^{\circ} 30^{\prime} \mathrm{S} 38^{\circ} 45^{\prime}-39^{\circ} 15^{\prime}$ $\mathrm{W}$, position NNE-SSW, located in the northeastern part of the state of Ceará, $70 \mathrm{~km}$ from the coast. This massif possesses a more humid windward side and a less humid lee side, which faces towards the interior (Gomes 1978, UFC/FUNCEME 1994, Souza 1997). The local climate is classified, according to Köppen's classification, as AW' (SEMACE 1992), with mean annual rainfall between 1100-1700 mm, and mean temperature below $24^{\circ} \mathrm{C}$, depending on altitudinal level (Nimer 1977, SUDENE 1982, FUNCEME 2010, INMET 2010). There are two main vegetation types that belong to the Atlantic rainforest Domain (Figueiredo and Barboza 1990, Fernandes 1998) which are named ombrophilous montane forest and seasonal semideciduous montane forest (Veloso et al. 1991). The former occurs only on the windward side and on the top, at altitudes above $600 \mathrm{~m}$, while the latter occupies areas below $600 \mathrm{~m}$, on the same side. On the lee side, above $600 \mathrm{~m}$, the seasonal deciduous montane forest occurs and below 500$600 \mathrm{~m}$ a thorny deciduous vegetation identified as “caatinga arbórea” prevails (Fernandes 1998).

In our study areas, we identified two basic landscape units: the forest fragments and the anthropogenic matrix which has been without agricultural use for the last 30 years, although occasional animal husbandry occurs.

Our study was carried out in Baturité, Guaramiranga and Mulungu municipalities, in four out of six fragments previously studied by Araújo et al. (2006a, b). These were named F1, F2, F3 and F4. 
The geographic location and characteristics of each site are as follows:

F1 (4²'24.3" S and 38 $\left.58^{\circ} 14.1^{\prime \prime} \mathrm{W}\right)$, at Sítio Lagoa, ombrophilous montane forest, on the windward side, 20.61 ha, at altitudes 1015-1114 m, municipality of Guaramiranga.

F2 (04 ${ }^{\circ} 15^{\prime} 16.0^{\prime \prime} \mathrm{S}$ and $38^{\circ} 59^{\prime} 31.5^{\prime}$ 'W), at Sítio Salva-Vidas, seasonal deciduous montane forest, 15.97 ha, on the lee side, at altitudes 670-690 m, municipality of Guaramiranga.

F3 (04 $16^{\prime} 57.1^{\prime \prime} \mathrm{S}$ and $39^{\circ} 00^{\prime} 01.1^{\prime \prime} \mathrm{W}$ ), at Sítio Jardim, seasonal deciduous montane forest, $26.45 \mathrm{ha}$, on the lee side, at altitudes $780-790 \mathrm{~m}$, municipality of Mulungu.

F4 (04¹8'08.35" S and 38 $\left.54^{\prime} 46.0^{\prime \prime} \mathrm{W}\right)$, at Sítio Labirinto dos Taveiras, ombrophilous montane forest, $6.30 \mathrm{ha}$, on the windward side, at altitudes 660- 680 m, municipality of Baturité.

In order to better represent massif vegetation, we selected two fragments of two vegetation types on each mountain side. We used only the immediate edges of these fragments named E1, E2, E3 and E4. The edge $\mathrm{E} 1 \mathrm{was} 600 \mathrm{~m}$ long and width varied between 1 to 2 $\mathrm{m}, \mathrm{E} 2$ was $400 \mathrm{~m}$ long and width varied between 2 and $10 \mathrm{~m}$, E3 was $600 \mathrm{~m}$ long and width between 1 to 2 $\mathrm{m}$ and $\mathrm{E} 4$ was $400 \mathrm{~m}$ long and width between 1 to 2 $\mathrm{m}$. The four edges summed up 1.11 ha. The vegetation found in the four edges showed the same patterns: low vegetation, bushy-herbaceous composition and variable degrees of permeability. Arboreal species, remnants of their respective forest fragments, were also present in punctual distribution throughout these edges.

\section{Data Collection AND ANALyses}

Field work was carried out monthly from March 2008 to August 2009. Botanical material was collected along a transect walked for one hour, twice in the morning and twice in afternoon shift, between 7 and $17 \mathrm{~h}$. Therefore, all edges were sampled for four hours per day, totaling $72 \mathrm{~h}$ per edge during the whole study. In all edges, we sampled solely plants that stingless bees used for pollen or nectar, by direct observation of these bees foraging on the open flowers (Menezes et al. 2007). Each plant was observed for approximately five minutes before it was harvested. Only fertile branches containing buds and open flowers were vouchered following Fidalgo and Bononi (1989). Vouchers were deposited in the Prisco Bezerra Herbarium (EAC) of Universidade Federal do Ceará, in Fortaleza (collector numbers refer to L. W. Lima-Verde and J. R. Lima).

To identify plant species, we consulted literature and the EAC Herbarium collection. Species and authors names were written in accordance with Brummitt and Powell (1992) and W3TROPICOS (2010). Families were classified according to the Angiosperm Phylogeny Group (APG) III (Bremer et al. 2009).

Plants were classified into four growth-form according to Whittaker (1975): herbs, shrubs, climbing (woody and herbaceous) and trees.

Data were organized in a binary matrix (presence/ absence) of the sampled species so as to evaluate the degree of association between floristic composition at the edges and the influence of rainfall gradients on the number of flowering species. To interpret the floristic composition at edges, we used a similarity coefficient (Jaccard index $\geq 0,50$, Kent and Coker 1992) and a cluster analysis (UPGMA), using Estimate S (Colwell 2006) and Biodiversity Pro version 2.0 (McAleece 1997). Pearson's correlation $(\mathrm{P} \in[-1,1]$, Zar 1984) was used to test the rainfall effects on species flowering using the software $\mathrm{R}$ (R Development Core Team 2010).

The seasonality of floristic resources was plotted as a function of monthly mean rainfall for each municipality. We considered a period of 12 months (January-December), to define the two local well-marked seasons: the wet season (NovemberJune) and the dry season (July-October). In this case we used the data pertaining to rainfall from March to December 2008 and January to February 2009. Historical monthly rainfall ranges were recorded for 1974-2010 (FUNCEME 2010, INMET 2010). 


\section{RESULTS}

\section{TAXONOMIC PATTERN IN THE FLORA}

In all study areas we recorded a total of 82 plant species, 72 genera and 33 families used as food resource by stingless bees (Table I). Five species were identified only at the genus level.
At the edge of each study area, we recorded 32 species, 30 genera and 18 families in E1; 25 species, 25 genera and 16 families in E2; 36 species, 32 genera and 18 families in E3; and 16 species, 16 genera and 11 families in E4.

The most common botanical families whose species were used by stingless bees in the four edges

\section{TABLE I}

Plant species used by stingless bees in four fragment edges of Atlantic rainforest at Baturité massif, state of Ceará, Brazil. E1 = Sítio Lagoa, ombrophilous montane forest (windward); E2 = Sítio Salva-Vidas, seasonal deciduous montane forest (leeward); E3 = Sítio Jardim, seasonal deciduous montane forest (leeward); E4 = Sítio Labirinto dos Taveiras, ombrophilous montane forest (windward). Habit (herb = herbaceous, $\mathbf{s h r}=$ shrubby, cli $=$ climbing, arb $=$ arboreal $)$, flowering period $(\mathrm{Jan}=\mathrm{January}$, Feb $=$ February, Mar $=$ March, Apr $=$ April, May $=$ May, Jun $=$ June, Jul $=$ July, Aug $=$ August, Sep $=$ September, Oct $=$ October, Nov $=$ November, Dec $=$ December .

\begin{tabular}{|c|c|c|c|}
\hline Families/species & Edge & Growth-form & Flowering period \\
\hline \multicolumn{4}{|l|}{ Amaranthaceae } \\
\hline Alternanthera brasiliana (L.) Kuntze & E2 & herb & Jul/Aug \\
\hline Irecine cf. diffusa Humb. Bonpl. ex Willd. & E1 & $\operatorname{shr}$ & $\mathrm{Jul} / \mathrm{Sep}$ \\
\hline \multicolumn{4}{|l|}{ Amaryllidaceae } \\
\hline Hippeastrum stylosum Herb. & E1 & herb & Oct \\
\hline \multicolumn{4}{|l|}{ Anacardiaceae } \\
\hline Myracrodruon urundeuva Allemão & E2 & arb & Sep \\
\hline Spondias mombin L. & E3 & arb & Dec/Jan \\
\hline \multicolumn{4}{|l|}{ Annonaceae } \\
\hline Xylopia frutescens Aubl. & E4 & arb & Mar \\
\hline \multicolumn{4}{|l|}{ Apocynaceae } \\
\hline Forsteronia glabrescens Müll. Arg. & E1 & cli & Oct/Nov \\
\hline Mandevilla scabra (Hoffmann. ex Roem. \& Schult.) K. Schum & E4 & cli & May/Jul \\
\hline Peltastes peltatus (Vell.) Woodson & E1 & cli & Nov \\
\hline \multicolumn{4}{|l|}{ Araliaceae } \\
\hline Oreopanax capitatus (Jacq.) Decne. \& Planch. & E1 & arb & Nov \\
\hline \multicolumn{4}{|l|}{ Asteraceae } \\
\hline Baccharis sp. & E1 & $\operatorname{shr}$ & Nov/Dec \\
\hline Bidens bipinnata $\mathrm{L}$. & $\mathrm{E} 2, \mathrm{E} 4$ & herb & May/Jun \\
\hline Cosmus caudatus Kunth & $\mathrm{E} 2, \mathrm{E} 3$ & herb & May/Jul, May/Jun \\
\hline Trichogoniopsis adenantha (DC.) R. M. King \& H. Rob. & E2 & $\operatorname{shr}$ & May/Jun \\
\hline Verbesina diversifolia $\mathrm{DC}$. & E1 & $\operatorname{shr}$ & Mar/Jun \\
\hline Vernonanthura brasiliana (L.) Druce & $\mathrm{E} 1, \mathrm{E} 2, \mathrm{E} 3$ & $\operatorname{shr}$ & Nov/Dec, Aug/Jan, Jun/Dec \\
\hline Vernonia scorpioides (Lam.) Pers. & E1, E4 & shr & Aug/Sep, Mar/Apr \\
\hline Wedelia scaberrima Benth. & $\mathrm{E} 2, \mathrm{E} 3$ & $\operatorname{shr}$ & Feb/May, Mar/May \\
\hline \multicolumn{4}{|l|}{ Begoniaceae } \\
\hline Begonia sp. & E1 & herb & Mar/May \\
\hline Arrabidaea cf. limae A. H. Gentry & E1 & cli & Nov/Dec \\
\hline Banisteriopsis lutea (Griseb.) Cuatrec. & E3 & cli & Oct \\
\hline Fridericia sp. & $\mathrm{E} 2, \mathrm{E} 3$ & cli & Nov/Dec, Oct/Nov \\
\hline Mansoa sp. & E3 & cli & Jun/Jul \\
\hline
\end{tabular}


TABLE I (continuation)

\begin{tabular}{|c|c|c|c|}
\hline Families/species & Edge & Growth-form & Flowering period \\
\hline \multicolumn{4}{|l|}{ Bixaceae } \\
\hline Cochlospermum vitifolium (Willd.) Spreng. & E2 & arb & Aug/Sep \\
\hline \multicolumn{4}{|l|}{ Boraginaceae } \\
\hline Cordia trichotoma (Vell.) Arráb. ex Steud. & E2, E3 & arb & Jun/Aug, Jun/Jul \\
\hline \multicolumn{4}{|l|}{ Caparaceae } \\
\hline Cynophalla flexuosa (L.) J. Prersl & E2, E3 & arb & Nov/Dec, Nov/Dec \\
\hline \multicolumn{4}{|l|}{ Convolvulaceae } \\
\hline Ipomoea hederifolia $\mathrm{L}$. & E3 & cli & Jul \\
\hline Jacquemontia nodiflora (Desr.) G. Don & E3 & cli & Jun/Jul \\
\hline Merremia aegyptia (L.) Urb. & E3 & cli & Jun/Jul \\
\hline \multicolumn{4}{|l|}{ Curcubitaceae } \\
\hline Momordica charantia $\mathrm{L}$. & E3 & cli & Jul/Aug \\
\hline \multicolumn{4}{|l|}{ Cyperaceae } \\
\hline Killinga odorata Vahl & E3 & herb & Mar/Jun \\
\hline \multicolumn{4}{|l|}{ Euphorbiaceae } \\
\hline Croton argyrophylloides Müll. Arg. & E3 & $\operatorname{shr}$ & Mar/Apr \\
\hline Croton blanchetianus Baill. & E2, E3 & $\operatorname{shr}$ & Feb/Mar, Mar/Apr \\
\hline Manihot glaziovii Müll. Arg. & E4 & arb & Dec/Mar \\
\hline \multicolumn{4}{|l|}{ Fabaceae } \\
\hline Albizia polycephala (Benth.) Killip. ex Record & E4 & arb & Mar/Apr \\
\hline Anadenanthera colubrina (Griseb.) Altschul var. cebil & E2 & arb & Dec/Jan \\
\hline Bauhinia aromatica Ducke & E3 & cli & Apr/May \\
\hline Bauhinia outimouta Aubl. & E1 & cli & Oct/Nov \\
\hline Cassia ferruginea (Schrad.) Schrad. ex DC. var. ferruginea & E1 & arb & $\mathrm{Dec} / \mathrm{Feb}$ \\
\hline Chamaecrista zigophylloides (Taub) H. S. Irwin \& Barneby & E3 & $\operatorname{shr}$ & Apr/May \\
\hline Inga bollandii Sprague \& Sandwith & E1 & arb & Sep/Nov \\
\hline Inga ingoides (Rich.) Willd. & E4 & arb & Sep/Oct \\
\hline Inga marginata Willd. & E1 & arb & Sep/Oct \\
\hline Libidibia ferrea var. parvifolia (Benth.) L. P. Queiroz & E3 & arb & Nov/Jan \\
\hline Mimosa arenosa (Willd.) Pior. & E2 & $\operatorname{shr}$ & May/Jun \\
\hline Piptadenia stipulacea (Benth.) Ducke & E2, E3 & arb & Nov/Dec, Dec/Jan \\
\hline Piptadenia viridiflora (Kunth) Benth. & E3 & arb & Sep/Oct \\
\hline Senagalia polyphylla (DC.) Britton \& Rose & E2, E3 & arb & Feb/Mar, Jan/Feb \\
\hline Senna georgica H. S. Irwin \& Barneby var. georgica & E1 & $\operatorname{shr}$ & Jun/Dec \\
\hline Senna splendida H. S. Irwin \& Barneby var. gloriosa & E3 & $\operatorname{shr}$ & Jul/Sep \\
\hline Senna uniflora (P. Miller) H. S. Irwin \& Barneby & E2, E3 & $\operatorname{shr}$ & May/Jun, May/Jul \\
\hline \multicolumn{4}{|l|}{ Heliconiaceae } \\
\hline Heliconia psittacorum L. f. & E4 & herb & Mar/Nov \\
\hline \multicolumn{4}{|l|}{ Hypericaceae } \\
\hline Vismia guianensis (Aubl.) Pers. & E4 & arb & Dec/Jan \\
\hline \multicolumn{4}{|l|}{ Hippocrateaceae } \\
\hline Hippocratea volubilis $\mathrm{L}$. & E1 & $\operatorname{shr}$ & Nov \\
\hline \multicolumn{4}{|l|}{ Malvaceae } \\
\hline Sida rhombifolia $\mathrm{L}$. & E4 & $\operatorname{shr}$ & May/Jun \\
\hline Waltheria indica $\mathrm{L}$. & E2, E3 & $\operatorname{shr}$ & Jun/Aug, Jun/Aug \\
\hline \multicolumn{4}{|l|}{ Marcgraviaceae } \\
\hline Norantea guianensis Aubl. & E1 & cli & Dec/Jan \\
\hline \multicolumn{4}{|l|}{ Melastomataceae } \\
\hline Clidemia hirta (L.) D. Don & E4 & $\operatorname{shr}$ & May/Jun \\
\hline
\end{tabular}


TABLE I (continuation)

\begin{tabular}{|c|c|c|c|}
\hline Families/species & Edge & Growth-form & Flowering period \\
\hline Miconia cecidophora Naudin & E4 & arb & Mar/Apr \\
\hline Tibouchinia multiflora (Gardner) Cogn & E1 & $\operatorname{shr}$ & Oct/Dec \\
\hline \multicolumn{4}{|l|}{ Mytaceae } \\
\hline Campomanesia dichotoma (O. Berg) Mattos & $\mathrm{E} 1, \mathrm{E} 4$ & arb & Jan/Feb, Dec \\
\hline \multicolumn{4}{|l|}{ Mytaceae } \\
\hline Myrcia multiflora (Lam.) DC. & E2 & arb & Oct/Nov \\
\hline Myrcia splendens (Sw.) DC. & $\mathrm{E} 1, \mathrm{E} 4$ & arb & Oct/Nov \\
\hline Eugenia sp. & E1, E3 & arb & $\mathrm{Jan} / \mathrm{Feb}, \mathrm{Mar} / \mathrm{Apr}$ \\
\hline \multicolumn{4}{|l|}{ Nyctaginaceae } \\
\hline Neea obovata Spruce ex Heimerl & E2, E3 & arb & Jan/Feb, Oct \\
\hline \multicolumn{4}{|l|}{ Plantaginaceae } \\
\hline Scoparia dulcis L. & E1, E3 & $\operatorname{shr}$ & Mar/Jul, Feb/Jul \\
\hline \multicolumn{4}{|l|}{ Polygalaceae } \\
\hline Polygala paniculata $\mathrm{L}$. & $\mathrm{E} 2$ & herb & Jun/Jul \\
\hline \multicolumn{4}{|l|}{ Rubiaceae } \\
\hline Alseis floribunda Schott & E2, E3 & arb & Jan, Apr/May \\
\hline Palicourea marcgravii A. St.-Hil. & E4 & $\operatorname{shr}$ & Mar/Apr \\
\hline Spermacoce verticillata $\mathrm{L}$. & $\mathrm{E} 1, \mathrm{E} 2, \mathrm{E} 3, \mathrm{E} 4$ & $\operatorname{shr}$ & May/Oct, May/Aug, Mar/Aug, May/Sep \\
\hline \multicolumn{4}{|l|}{ Salicaceae } \\
\hline Banara guianensis Aubl. & E1 & arb & $\mathrm{Jan} / \mathrm{Fev}$ \\
\hline Casearia silvestris $\mathrm{Sw}$. & E1 & arb & Dec \\
\hline Xylosma ciliatifolium (Clos) Eichler & E1 & arb & Dec \\
\hline \multicolumn{4}{|l|}{ Solanaceae } \\
\hline Acnistus arborescens (L.) Schltdl. & E1 & $\operatorname{shr}$ & Apr/Nov \\
\hline Solanun baturitense Huber & E3 & $\operatorname{shr}$ & Jan/Dez \\
\hline Solanum caavurana Vell. & E1 & $\operatorname{shr}$ & Nov/Dec \\
\hline Solanum paniculatum L. & E1, E2, E3 & $\operatorname{shr}$ & Jun/Jan, Jan/Dec \\
\hline \multicolumn{4}{|l|}{ Thymeliaceae } \\
\hline Daphnopsis racemosa Griseb. & E1 & $\operatorname{shr}$ & Nov/Dec \\
\hline \multicolumn{4}{|l|}{ Verbenaceae } \\
\hline Lantana canescens Kunth & E3 & $\operatorname{shr}$ & Mar/Apr \\
\hline Vitex triflora Vahl & E3 & arb & Dec \\
\hline
\end{tabular}

were Fabaceae (11 genera and $17 \mathrm{spp}$.) and Asteraceae ( 8 genera and 8 spp.), followed by Bignoniaceae (4 genera and 4 spp.), Myrtaceae (3 genera and 4 spp.), Solanaceae (2 genera and 4 spp.), Apocynaceae (3 genera and 3 spp.), Convolvulaceae (3 genera and 3 spp.), Euphorbiaceae (2 genera and 3 spp.), Salicaceae (3 genera and $3 \mathrm{spp}$.) Melastomataceae ( 3 genera and 3 spp.) and Rubiaceae ( 3 genera and 3 spp.). It is worth mentioning that we did not record Asteraceae in E4. These families represented 67.07\% of the species visited by stingless bees.

The seven most species-rich genera were Senna, Inga, Solanum, Croton, Bauhinia, Piptadenia and Myrcia. The first three genera had three species each, while the remaining had two species each (Table I).

FOOD SUPPLY PATTERN

The plant species Spermacoce verticillata (Rubiaceae), Libidibia ferrea (Fabaceae), Serjania lethalis (Sapindaceae) Vernonanthura brasiliana (Asteraceae), Cynophalla flexuosa (Capparaceae), Senna splendida (Fabaceae) and Wedelia scaberrima (Asteraceae), offered most of the food resource to a total of 20 stingless bee species recorded (L.W. Lima-Verde and B.M. Freitas, unpublished data). 
S. verticillata occurred in all areas and offered resources to $60 \%$ (12 spp.) of visitors. L. ferrea occurred only in E3 and was visited by 35\% (7 spp.) of the bees. S. lethalis and $V$. brasiliana recorded in E1 and E3, and E1, E2 and E3, respectively, were visited by $30 \%$ (6 spp.) of the bee species. C. flexuosa occurred in E2 and E3 and offered resources to $25 \%$ (5 spp.) of the bees. $S$. splendida (E3) and W. scaberrima (E2 and E3), offered, each one, resources to $20 \%$ (4 spp.) of the meliponine bees.

\section{GROWTH-FORM PATTERN OF FLORA}

Trees and shrubs were the predominant growthform in the edges studied, however in E3 the climbing plant richness matched that of the trees, both with ten species (Fig. 1).

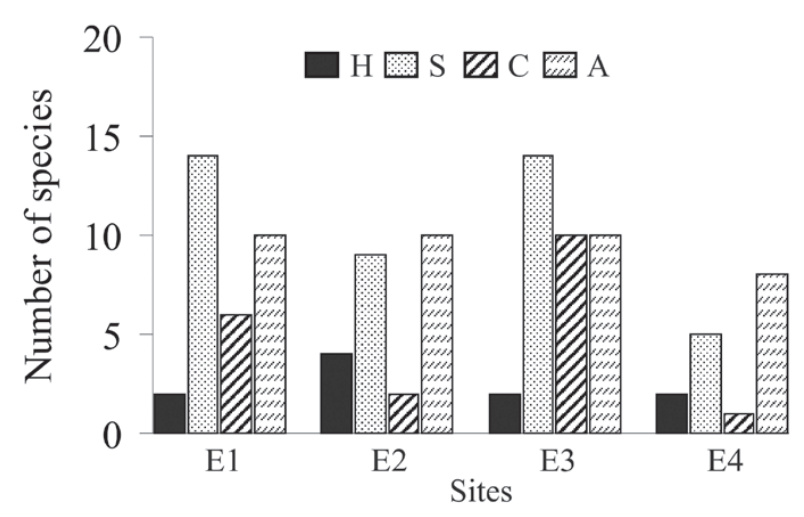

Figure 1 - Number of plant species per growth-form in four fragment edges of the Atlantic rainforest at Baturité massif, state of Ceará, Brazil. $\mathrm{H}=$ herbaceous; $\mathrm{S}=$ shrubby; $\mathrm{C}=$ climbing; $\mathrm{A}=$ arboreal. $\mathrm{E} 1$ = Sítio Lagoa, ombrophilous montane forest (windward); E2 = Sítio Salva-Vidas, seasonal deciduous montane forest (leeward); E3 = Sítio Jardim, seasonal deciduous montane forest (leeward); E4 = Sítio Labirinto dos Taveiras, ombrophilous montane forest (windward).

\section{FLORISTIC SIMILARITY}

The cluster analysis among the flora of all edges ranged from $2.04 \%$ to $31.11 \%$ for the Jaccard index (Table II).

The dendrogram of similarity among the edges (Fig. 2) formed two groups. Clearly, this was more related to vegetation typologies and to the mountain
TABLE II

Floristic similarity and distance $(\mathrm{km})$ between four fragment edges of Atlantic rainforest at Baturité massif, state of Ceará, Brazil. E1 = Sítio Lagoa, ombrophilous montane forest (windward); E2 =

Sítio Salva-Vidas, seasonal deciduous montane forest (leeward); E3 = Sítio Jardim, seasonal deciduous montane forest (leeward); E4 = Sítio Labirinto dos Taveiras, ombrophilous montane forest (windward).

\begin{tabular}{ccc}
\hline $\begin{array}{c}\text { Fragment } \\
\text { Edge }\end{array}$ & Jaccard's Coefficient (\%) & Distance (km) \\
\hline E1 x E2 & 5.55 & 3.23 \\
E1 x E3 & 10.00 & 9.01 \\
E1 x E4 & 9.09 & 3.96 \\
E2 x E3 & 31.11 & 5.79 \\
E2 x E4 & 5.13 & 10.27 \\
E3 x E4 & 2.04 & 12.36 \\
\hline
\end{tabular}

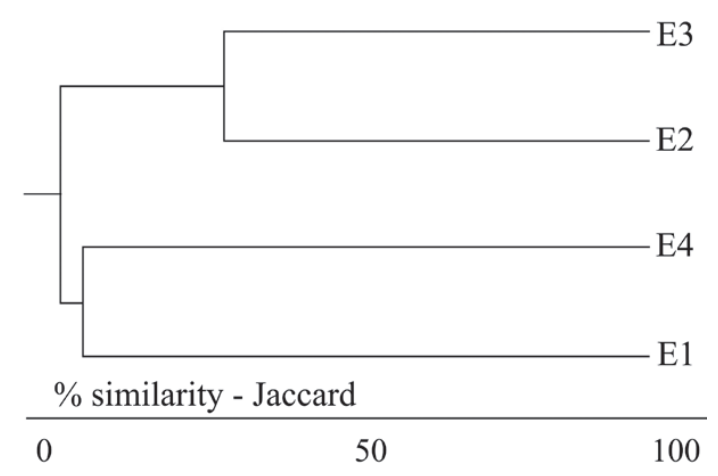

Figure 2 - Dendrogram of floristic similarity between four fragment edges of the Atlantic rainforest at Baturité massif, state of Ceará, Brazil. E1 = Sítio Lagoa, ombrophilous montane forest (windward); E2 = Sítio Salva-Vidas, seasonal deciduous montane forest (leeward); E3 = Sítio Jardim, seasonal deciduous montane forest (leeward); E4 = Sítio Labirinto dos Taveiras, ombrophilous montane forest (windward).

sides (on the windward ombrophilous montane forest, for E1 x E4, and on the leeward seasonal semideciduous montane forest, for E2 x E3).

The pattern of flora distribution in the study areas also showed that only S. verticillata, Solanum paniculatum and $V$. brasiliana $(3.66 \%$ of the total recorded species) occurred in at least three edges, suggesting a high plasticity of these species in relation to geographical location. A total of $28.05 \%$ of species (23 spp.) were present at only two edges and $68.29 \%$ (56 spp.) were unique to an edge (Table I). 
FLOWERING VERSUS RAINFALL

Analysis of the number of flowering species related to annual rainfall also showed somewhat different features in the study areas (Figs. 3 and 4).

In $\mathrm{E} 1$, there was a negative correlation $(\mathrm{r}=$ - $0.68 ; p=0.01)$. In $\mathrm{E} 2$, results were not statistically significant, with a low correlation $(\mathrm{r}=0.18 ; p=0.58)$. In E3 and E4 correlations were highly positive ( $\mathrm{r}=0.64, p=0.02 \mathrm{r}=0.71, p=0.009$, respectively), especially in $\mathrm{E} 4$.

Regarding flowering periods, we found that the fragment edges had suites of species with an overlapping flowering sequence, which can offer resources to bees through the year.

Edge E1: Norantea guianensis (DecemberFebruary), Scoparia dulcis (March-July), Acnistus arborescens (April-November), Spermacoce
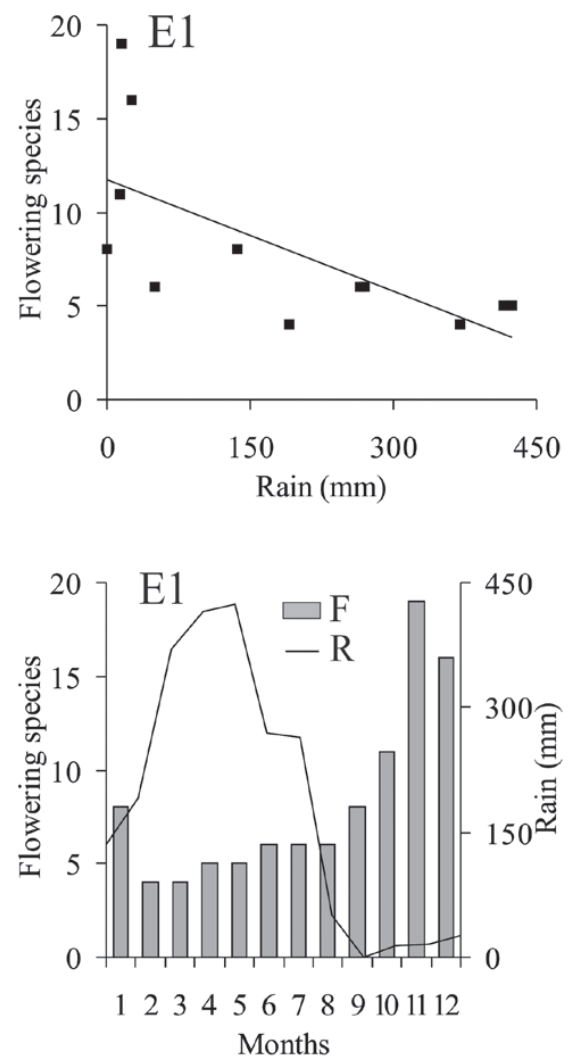

verticillata (May-October), Inga bollandii (SeptemberNovember), Vernonanthura brasiliana (NovemberDecember), Serjania lethalis (November-December).

Edge E2: Cardiospermum corindum (JanuaryDecember), Senegalia poliphylla (February-March), Wedelia scaberrima (February-May), Spermacoce verticillata (May-August), Capparis flexuosa (November-December), Anadenathera colubrina (December-January), Vernonanthura brasiliana (August-January).

Edge E3: Scoparia dulcis (February-July), Wedelia scaberrima (March-May), Spermacoce verticillata (March-August), Senna uniflora (MayJuly), Vernonanthura brasiliana (June-December), Senna splendida (July-September), Serjania lethalis (October-December), Capparis flexuosa (NovemberDecember), Spondias mombin (December-January).
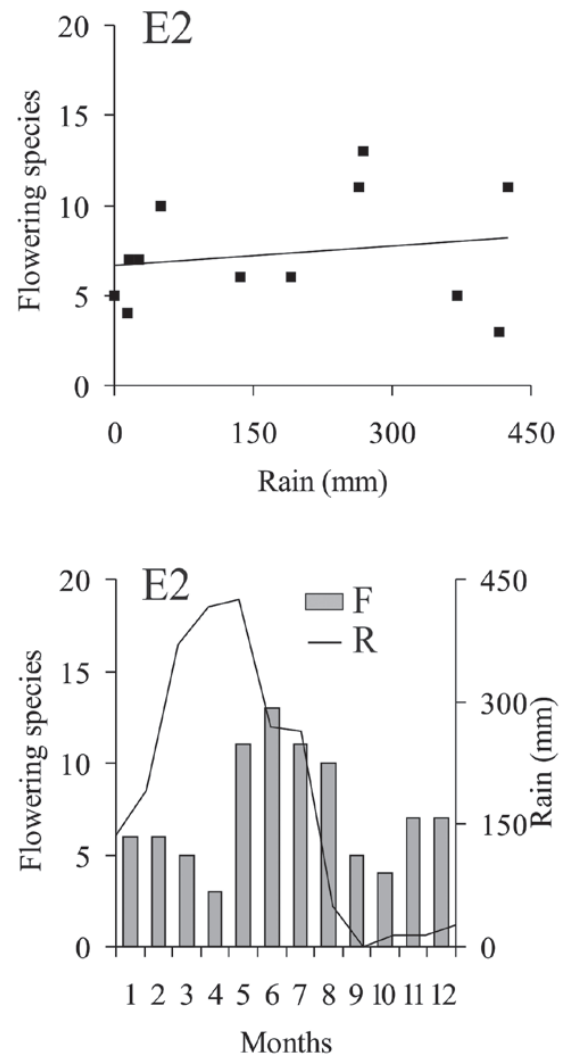

Figure 3 - Dendrogram of dispersion and flowering chronology of the plant species surveyed at edges E1 and E2 of the Atlantic rainforest at Baturité massif, state of Ceará, Brazil. $\mathrm{R}=$ Rain; $\mathrm{F}=$ Flowering species. Rains from March to December 2008 and from January to February 2009, based on the historical average from 1974 to 2010. E1 = Sítio Lagoa, ombrophilous montane forest (windward); E2 = Sítio Salva-Vidas, seasonal deciduous montane forest (leeward). 

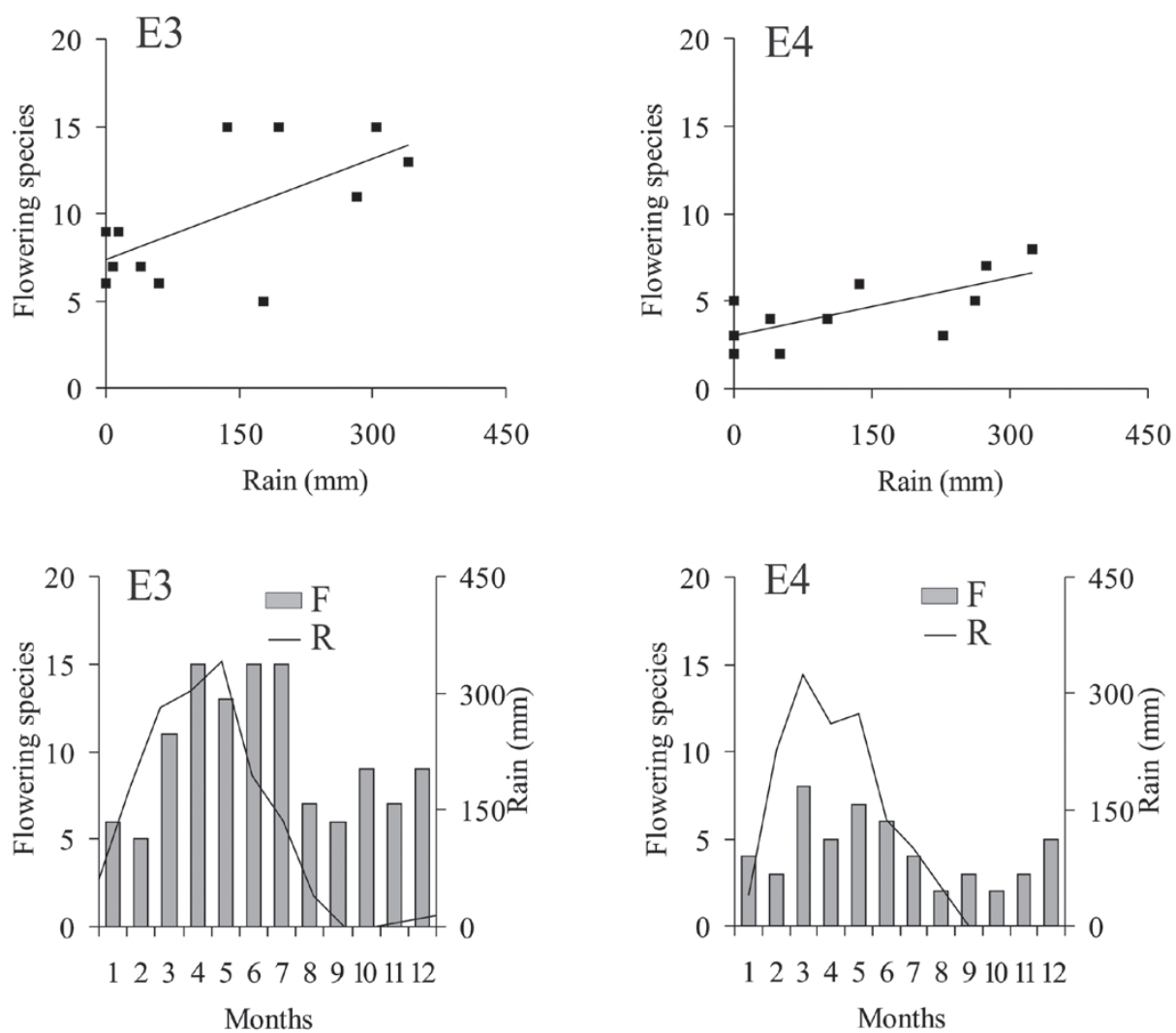

Figure 4 - Dendrogram of dispersion and flowering chronology of the plant species surveyed at edges E3 and E4 of the Atlantic rainforest at Baturité massif, state of Ceará, Brazil. $\mathrm{R}=$ Rain; F = Flowering species. Rains from March to Dezember 2008 and from January to February 2009, based on the historical average from 1974 to 2010. E3 = Sítio Jardim, seasonal deciduous montane forest (leeward); E4 = Sítio Labirinto dos Taveiras, ombrophilous montane forest (windward).

Edge E4: Manihot glaziovii (December-March), Heliconia psittacorum (March-November), Albizia polycephala (March-April), Miconia cecidophora (March-April), Spermacoce verticillata (MaySeptember), Inga ingoides (September-October), Myrcia splendens (October-November).

\section{DISCUSSION}

\section{TAXONOMIC PATTERN AMONG THE FLORA}

Our results showed a wide range of trophic sources for stingless bees, owing to high floristic diversity (82 species, 72 genera and 33 families).

Our findings are similar to those few studies on plant species important as food resources to the bees from Atlantic forest in this portion of Brazil (Milet-Pinheiro and Schlindwein 2008, 87 species, 76 genera and 38 families; and Locatelli et al.
2004, 63 species, 50 genera and, 29 families). In addition, in this same region, our results are also in agreement with Oliveira et al. (2006), who studied edges with types of low vegetation ("capoeira") (90 species, 74 genera and 74 families).

Among the eleven most common botanical families whose species were used by stingless bees, Fabaceae and Asteraceae had the largest number of species. Fabaceae also had the most speciesrich genera, such as Senna, Inga, Bauhinia and Piptadenia (Table I).

These two families stand out in several studies in tropical region, due to their wide geographic distribution and the considerable number of species among the Angiospermae Cronquist 1981). In Brazil, this pattern of richness has also been reported in many ecosystems through floristic and 
hymenopteran surveys (e.g.: Viana et al. 1997, in the Cerrado, Aguiar 2003, in the Caatinga, FariaMucci et al. 2003, in the Campos Rupestes, Viana and Kleinert 2006, in the Restinga, Locatelli et al. 2004 and Milet-Pinheiro and Schlindwein 2008, in the Atlantic Forest Domain).

\section{FOOD SUPPLY PATTERN}

The most important species that offer food resources to stingless bees (S. verticillata, L. ferrea, S. lethalis, V. brasiliana, C. flexuosa, S. splendida, $W$. scaberrima) must initially be taken into account when managing these areas.

In forest patch edges in the Baturité massif, these species are believed to ensure the maintenance of several species of local stingless bees as well as enabling, in part, a successful local meliponiculture.

Among these seven species mentioned above, $S$. verticillata is noteworthy for being the most important for the stingless bees. Its spectrum of flowering ranged from four to six months between March and October, at the edge of each forest fragment, showing therefore, a period of supply of food resources, both in the months of highest rainfall, as those less rainy in Baturité massif. S. verticillata has also presented a considerable adaptive plasticity to habitat and soil types at different levels of degradation, showing how their subjects are rustic to the diversity of the medium. Studies in similar Brazilian ecosystems with bees census (Wilms et al. 1996, Gonçalves and Melo 2005, Viana et al. 2006) also showed the importance of $S$. verticillata for this group of Hymenoptera.

\section{GROWTH-FORM PATTERN OF THE FLORA}

Owing to the criteria used for definition of edges, the shrub and arboreal growth-form were prevalent (Fig. 1), both for having the highest species richness at the immediate edges and for distribution in the rest of the matrix.

In the field it was observed that the shrub species were more or less enclosed space edges with a higher degree of degradation. Studies such as Bierregaard et al. (1992) and Murcia (1995) show that the transformations undergone by these environments radically alter levels of light, humidity, temperature and air currents. In this case, the structure and species richness of vegetation edge depend heavily on the type of surrounding matrix and the edge effect.

In summary, the successful occupation of these areas by species groups are associated with different abiotic conditions of the edges and consequently with greater or lesser difficulty of dispersal of propagules of some species (Scariot et al. 2003).

In general, species of degraded fragments forest are characterized by the requirement in brightness due to its high regeneration capacity and dispersion vegetative propagules (Maciel et al. 2011).

The environmental conditions of the collection sites also seem to bring different responses to the predominance of growth-forms. Studies of Locatelli et al. (2004) and Milet-Pinheiro and Schlindwein (2008) demonstrated this possibility by recording the herbaceous growth-form was prevalent in the first study, and herbaceous and shrub were more predominant in the second.

\section{FLORISTIC SIMILARITY}

Our data showed a considerable degree of heterogeneity in the floristic compositions (Table I), which was evidenced by the low values in the cluster analysis (Jaccard's index).

In Table I, we note that the distances between edges did not significantly account for floristic similarity among them. However, vegetation type explained better this floristic similarity in all areas. Groupings E1 x E4 and E2 x E3 (Fig. 2) were defined, respectively, by their vegetation types (ombrophilous montane forest and the seasonal semideciduous montane forest) and, consequently, by mountain side orientation (windward or leeward).

The difference in species number between areas may be associated with the conservation 
status and with matrix permeability. The matrix characteristics are usually related to the degree of disturbance, to inadequate soil management, to a greater or lesser light incidence, as well as to the size of the area (Cane 2001, Scariot et al. 2003, Ewers and Didham 2006).

However, one must consider local topoclimatic factors. Gentry $(1982,1988)$ and Murphy and Lugo (1986) verified, in neotropical forest fragments, that the greatest plant species richness is positively correlated with the levels of annual rainfall and climate seasonality. As for Baturité massif remnants, Araújo et al. (2006b) found that an increase in floristic richness was correlated with the elevation of the altitudinal gradient. This floristic richness could also be related with the local rainfall gradient, which, according to Nimer (1989), in mountains like Baturité massif increases with increasing altitude.

We also noted that species richness was correlated to climatic and altitudinal conditions. In E2, located between 670 and $690 \mathrm{~m}$, we recorded 25 species, while in E3 (780-790 m) we recorded 36 species. We found similar results in E1 (1015$1114 \mathrm{~m}$ ) and E4 (660-680 m) where we recorded 32 and 16 species, respectively.

Flowering VERSUS RAINFALl CORRELATION

All the edges showed different magnitudes with relation to the number of flowering species as indicated by Pearson's coefficients (Figs. 3 and 4).

In E1, there was a high negative correlation $(r=-0.68)$, thus showing a low number of flowering species during the period of greater rainfall. In this case, the flowering peak occurred between September and January, during the dry season.

In E2, the low positive correlation was not statistically significant and seems to indicate that in this area the flowering season is more evenly distributed throughout the year. However, we found that the flowering peak tended to occur between May and August, when rainfall began to decrease.
In the last two areas (E3 and E4), the correlations were high and positive $(r=0.64$ and $r=0.71$, respectively), which indicates that the number of flowering species responded better to annual rainfall. The number of flowering species decreased as rainfall decreased. For these edges a second flowering peak occurred, chiefly in the last months of the year.

Numerous environmental factors may be operating in these areas, however, those related to climate and topography are more easily perceptible to the conditions of the Baturite massif as the observations of Araújo et al. (2006a, b).

In Brazil, phenological studies covering all aspects of the flora of forest types, such as Atlantic forest, have shown that in environments with seasonally defined climates, the flowering periods of most species generally depend on the alternation of seasons (Morellato et al. 1989, 1990, Morellato and Leitão-Filho 1990, Talora and Morellato 2000). These species depend, therefore, on climatic factors, mainly related to the humidity and temperature, to trigger their phenophases of flowering.

\section{SUGgESTIONS FOR MANAGEMENT}

Maintenance of forest or remnant forest patch edges under proper management conditions would enable in situ biological conservation, especially benefiting meliponine bees, as well as other pollinators.

Antonini et al. (2003) indicate the need for maintaining the successional vegetation around forest fragments as an essential preservation measure for bees in general. On the other hand, Britez et al. (2003) highlight that when planning management activities around forest fragments, one must consider the landscape itself, proper management techniques, monitoring diagnostics of the flora and fauna, water resources and the physical environment.

At present, the main issue study areas is human and animal trampling, especially cattle, which has a seasonal grazing schedule. In this case, it is important that we develop some techniques for 
environmental protection to be used on the occasion of procedures for monitoring these areas.

A simple and practical suggestion, in conformity with López-Barrera (2004), is to try to conserve these areas as important wildlife and wild land preserves in the category of low vegetation, with soft permeability and high light incidence. Such measures would maintain these edges in this status $q u o$, so that more effective preservation measures, such as ecological corridors or connecting isolated patches, can be established and benefit these forest fragments as a whole.

\section{CONCLUSIONS}

The large number of Meliponina species which visited the flowers of plant species occurring at the forest fragment edges proves the importance of this flora as a trophic resource for the stingless bees in the Baturité massif.

Forest fragment edges in the Baturité massif constitute an ample spectrum of trophic resources to a degraded environment providing 82 plant species visited by Meliponina bees.

The species Spermacoce verticillata, Libidibia ferrea, Serjania lethalis, Vernonanthura brasiliana, Cynophalla flexuosa, Senna splendida and Wedelia scaberrima outstand the others as providers of food resources to the stingless bees and $S$. verticillata can be considered the most important of them, both for its plasticity being preset in the four studied edges, as well as for offering resources for 12 out of the 20 Meliponina species present in the area.

Despite occurring in the same massif formation, the four forest fragment edges bear heterogeneous flora, suggesting a differentiated geographic distribution of these plant species in the edges studied.

The distinct effects of rain levels on the blooming of plant species found at each fragment edge determines how flowering phenology takes place in these areas and also shows how each floristic component presents its temporal alternative of trophic resources to the guilds of local stingless bees.

\section{ACKNOWLEDGMENTS}

The authors thank BNB/ETENE/FUNDECI (project 1835/2008), Fundação Cearense de Apoio ao Desenvolvimento Científico e Tecnológico (Funcap) and Conselho Nacional de Desenvolvimento Científico e Tecnológico (CNPq, Brasília/Brazil) for financial support, a D.Sc. scholarship to L.W. Lima-Verde and a research grant to B.M. Freitas (\#305062/2007-7), respectively. We also acknowledge the biologists Francyregis Araújo Nunes, Alípio José de Souza Pacheco Filho and Andréa Pereira Silveira for their support in organizing the statistical calculations and the graphics. Finally, we are grateful to all the landowners for allowing us to collect data within their properties.

\section{RESUMO}

Informações sobre o uso dos recursos florísticos de bordas imediatas de fragmentos de floresta atlântica pelas abelhas sem ferrão não estão facilmente disponíveis na literatura científica. Considerando a importância dessas espécies vegetais para as guildas de meliponíneos locais, este estudo objetivou identificar e caracterizar a flora das bordas imediatas de quatro fragmentos florestais de mata atlântica situados no maciço de Baturité, no estado do Ceará, usada como recurso alimentar pelas abelhas sem ferrão. Estudamos as formas de crescimento das plantas, a similaridade florística entre bordas, os efeitos da pluviosidade sobre a floração e sugerimos técnicas simples para o manejo dessas áreas. Compilamos um total de 82 espécies vegetais, com predominância das formas arbóreas e arbustivas. Houve diferença na riqueza florística entre as áreas e a pluviosidade teve influência diferenciada sobre a floração, de acordo com a borda. Concluímos que os componentes florísticos das bordas estudadas são importantes para as guildas de abelhas sem ferrão, mas, práticas alternativas de manejo são necessárias para conservar as espécies vegetais e as abelhas.

Palavras-chave: floresta decídua, florística, habitat fragmentado, abelha sem ferrão, recurso trófico. 


\section{REFERENCES}

AGUiAR CML. 2003. Utilização de recursos florais por abelhas (Hymenoptera, Apoidea) em uma área de caatinga (Itatim, Bahia). Rev Bras Zool 20(3): 457-467.

ANTONINI Y, ACCACIO GM, BRANT A, CABRAL BC, FONTENELLE JCR, NASCIMENTO MT, THOMAZINI APBW AND THOMAZINI MJ. 2003. Efeitos da fragmentação sobre a biodiversidade - insetos. In: RAMBALDI DM AND OLIVEIRA DAS (Eds), Fragmentação de ecossistemas: causas, efeitos sobre a biodiversidade e recomendações de políticas públicas, Ministério do Meio Ambiente, Brasília, DF, p. 239-273.

ARAúJo FS, Gomes VS, Lima-VERdE LW, FigueIREdo MA, BRUNO MMA, NuNES EP, OTUTUMI AT AND RiBEIRO KA. 2006b. Efeito da variação topoclimática na composição e riqueza da flora fanerogâmica da serra de Baturité, Ceará. In: OLIVEIRA TS AND ARAÚJO FS (Eds), Diversidade e conservação da biota na serra de Baturité, Ceará, UFC/ COELCE, Fortaleza, Ceará, p. 137-162.

ARAúJo FS, GOMES VS, SilveIRA AP, FigueIREdo MA, OliVEIRA RF, BRUNO MMA, LIMA-VERDE LW, SilVA EF, OTUTUMI AT AND RIBEIRO KA. 2006a. Efeito da variação topoclimática na fisionomia e estrutura da vegetação da serra de Baturité, Ceará. In: OLIVEIRA TS AND ARAÚJO FS (Eds), Diversidade e conservação da biota na serra de Baturité, Ceará, UFC/COELCE, Fortaleza, Ceará, p. 73-136.

BierregaArd RO, Lovejoy TE, Kapos V, SAntos AA AND HutChINGS RW. 1992. The biological dynamics of tropical rainforest fragments. Bioscience 42(11): 859-866.

Bremer B, Bremer K, Chase MW, Fay MF, Reveal JL, Soltis DS, Soltis PS AND SteVens PF. 2009. An update of the Angiosperm Phylogeny Group classification for the orders and families of flowering plants: APG III. Bot J Linn Soc 161(2): 105-121.

BRITEZ RM ET AL. 2003. Gestão de paisagens fragmentadas e recomendações de políticas públicas: manejo do entorno, In: RAMBALDI DM And OLIVEIRA DAS (Eds), Fragmentação de ecossistemas: causas, efeitos sobre a biodiversidade e recomendações de políticas públicas, Ministério do Meio Ambiente, Brasília, DF, p. 347-365.

BRUMMITT RK AND POWELL CE. 1992. Authors of plant names, Royal Botanic Gardens, Kew, London, 732 p.

CANE JH. 2001. Habitat fragmentation and native bees: a premature verdict? Conserv Ecol 5(1): 3 .

Cerqueira R, Brant A, Nascimento MT and Pardini R. 2003. Fragmentação: alguns conceitos, In: RAMBALDI DM AND OLIVEIRA DAS (Eds), Fragmentação de ecossistemas: causas, efeitos sobre a biodiversidade e recomendações de políticas públicas, Ministério do Meio Ambiente, Brasília, DF, p. 23-40.

COLWELLRK. 2006. Estimate S: Statistical estimation of species richness and schared species from samples, Version 8.0, User's Guid and Application, University of Connecticut, (Available at: < http://purl.oclc.org/estimate $>$ ).
CRONQUIST A. 1981. An integrated system of classification of flowering plants. Columbia University Press, New York, $1262 \mathrm{p}$.

Cure JR, Thiengo M, Silveira FA And Rocha LB. 1992. Levantamento da fauna de abelhas silvestres na "Zona da Mata" de Minas Gerais. III. Mata secundária da região de Viçosa (Hymenoptera, Apoidea). Rev Bras Zool 9(3/4): 223-239.

EWERS RM AND DIDHAM RK. 2006. Confounding factors in the detection of species responses to habitat fragmentation. Biol Rev 81(1): 117-142.

FARIA-Mucci GM, Mel MA AND CAMpos LAO. 2003. A fauna de abelhas (Hymenoptera, Apoidea) e plantas utilizada como fontes de recursos florais, em um ecossistema de campos rupestres em Lavras Novas, Minas Gerais, Brasil. In: MELO GAR AND SANTOS IA (Eds), Apoidea Neotropica - homenagem aos 90 anos de Jesus Santiago Moure, UNESC Edições, Criciúma, Santa Catarina, p. 241-256.

FERNANDES A. 1998. Fitogeografia brasileira, Multigraf, Fortaleza, $340 \mathrm{p}$.

FidAlgo O AND BonOni VLR. 1989. Técnicas de coleta, preservação e herborização de material botânico, Instituto de Botânica (série documentos), São Paulo, 62 p.

Figueiredo MA AND BARBOZA MA. 1990. A vegetação e a flora da serra de Baturité, Ceará, Coleção Mossoroense (Série B) 747: 1-10.

FreITAS BM, IMPERATRIZ-FONSECA VL, MEDINA LM, KLEINERT AMP, Galeto L, NATES-PARRA G AND QuezadA-EuÁN JJ. 2009. Diversity, threats and conservation of nativee bees in the Neotropics. Apidologie 40(3): 332-346.

FUNCEME - FundaÇão CEARENSE dE MEteorologia E RECURSOS HídRICOS. 2010. Dados meteorológicos, FUNCEME, Fortaleza. (Available at: <http://www. funceme.br>).

GENTRY AH. 1982. Patterns of Neotropical plants species diversity. Evol Biol 15: 1-84.

GENTRY AH. 1988. Changes in plant community diversity and floristic composition on environment and geographical gradients. Ann Mo Bot Gard 75(1): 1-34.

GomEs MAF. 1978. O maciço de Baturité - uma abordagem ecológica. In: Anonymous (Eds), Anais do III Encontro Nacional de Geógrafos, AGB/UFC, Fortaleza, p. 39-59.

GonÇAlves RB AND Melo GAR. 2005. A comunidade de abelhas (Hymenoptera, Apidae) em uma área restrita de campo natural no Parque Estadual de Vila Velha, Paraná: diversidade, fenologia e fontes florais de alimento. Rev Bras Entomol 49(4): 557-571.

Gonçalves RB, Melo GAR And Aguiar AJC. 2009. A assembleia de abelhas (Hymenoptera, Apidae) de uma área de campos naturais do Parque Estadual de Vila Velha, Paraná e comparações com áreas de campos e cerrados. Pap Avul Zool 49(14): 163-181.

INMET - Instituto Nacional de Meteorologia. 2010. Relatório de pluviometria e temperaturas médias por faixa de anos (dados avulsos): Estado do Ceará, INMET, Brasília, DF. 
KENT M AND COKER P. 1992. Vegetation description and analysis, a practical approach, Belhaven Press, London, 363 p.

LOCATELli E, MACHADO ICS AND MEDEIROS P. 2004. Riqueza de abelhas e a flora apícola em um fragmento da mata serrana (Brejo de Altitude) em Pernambuco, Nordeste do Brasil. In: PÔRTO KC, CABRAL JJP AND TABARELLI M (Eds), Brejos de altitude em Pernambuco e Paraíba História Natural, Ecologia e Conservação, Ministério do Meio Ambiente, Brasília, DF, p. 153-177.

LÓPEZ-BARRERA F. 2004. Estructura y función en bordes de bosques. Ecosistems 13(1): 67-77.

Maciel LA, Siles MFR AND BITENCOURT MD. 2011. Alterações na vegetação herbácea de floresta ombrófila densa decorrentes do uso em uma trilha turística na Serra do Mar em São Paulo, Brasil. Acta Bot Bras 25(3): 628-632.

MCAleECE N. 1997. Bio Diversity Professonal versão 2.0, The Natural History Museum and The Schottish Association for Marine Science, Oban, Scotland. (Available at: $<$ http:// gcmd.nasa.gov/KeywordSearch $>$ ).

Menezes C, Silva CI, Singer RB And KerR WE. 2007. Competição entre abelhas durante forrageamento em Schefflera arboricola (Hayata) Merr. Jornal de Biociências 23(1): 63-69.

Milet-Pinheiro P AND SChlindwein C. 2008. Comunidade de abelhas (Hymenoptera, Apoidea) e plantas em uma área do agreste pernambucano, Brasil. Rev Bras Entomol 52(4): 625-636.

Monteiro D AND RAmalho M. 2010. Abelhas generalistas (Meliponina) e o sucesso reprodutivo de Stryphnodendron pulcherrimum (Fabales: Mimosaceae) com florada em massa na Mata Atlântica, BA. Neotrop Entomol 39(4): 519-526.

MoREllato LPC AND LEITÃO-FILHO HF. 1990. Estratégias fenológicas de espécies arbóreas em floresta mesófila na Serra do Japi, Jundiaí, SP. Braz J Biol 50(1): 163-173.

MORELLATO LPC, LEITÃo-FILHO HF, RODRIGUES RR AND JOLY CA. 1990. Estratégias fenológicas de espécies arbóreas em floresta de altitude na Serra do Japi, Jundiaí, SP. Braz J Biol 50(1): 149-162.

MORELlATO LPC, RODRIGUES RR, LEITÃO-FILHO HF AND JOLY CA. 1989. Estudo fenológico comparativo de espécies arbóreas de floresta de altitude e floresta mesófila semidecídua na Serra do Japi, Jundiaí, SP. Rev Bras Bot 12(1/2): 85-98.

MurCiA C. 1995. Edge effects in fragmented forests: implication for conservation Trends Ecol Evol 10(2): 58-62.

MurPhy PG AND LugO AE. 1986. Ecology of tropical dry forest. Annu Rev Ecol Syst 17(1): 67-88.

Nimer E. 1977. Relevo. In: Galvão MV (Ed), Geografia do Brasil: Região Nordeste, IBGE, Rio de Janeiro, p. 47-84.

OLIVEIRA FX, ANDRADE LA AND FÉLIX LP. 2006. Comparações florísticas entre comunidades de Floresta Ombrófila Aberta com diferentes idades, no Município de Areia, PB. Acta Bot Bras 20(4): 861-873.

RAMALHO M AND SILVA M. 2002. Flora oleífera e sua guilda de abelhas em uma comunidade de restinga tropical. Sitient Série Ciên Biol 2(1/2): 34-43.
R Development Core Team. 2010. R: A language and environment for statistical computing, R Foundation for Statistical Computing, Vienna, (Available at: <http:// www.R-project.org. $>$ ).

SCARIOT A, FrEITAS SR, NETO EM, NASCIMENTO MT, OLIVEIRA LC, SANAiotti T, SEVILHA AC AND Villela DM. 2003. Efeitos da fragmentação sobre a biodiversidade-vegetação e flora. In: RAMBALDI DM AND OLIVEIRA DAS (Eds), Fragmentação de ecossistemas - causas, efeitos sobre a biodiversidade e recomendações de políticas públicas, Ministério do Meio Ambiente/ SBF, Brasília, DF, p. 103-123.

SCHNEIDER MPC ET AL. 2003. Efeitos da fragmentação sobre a biodiversidade - genética de populações naturais. In: RAMBALDI DM AND OLIVEIMRA DAS (Eds), Fragmentação de ecossistemas - causas, efeitos sobre a biodiversidade e recomendações de políticas públicas, Ministério do Meio Ambiente/ SBF, Brasília, DF, p. 297-315.

SEMACE - SUPERINTENDÊNCIA ESTADUAL DO MEIO AMBIENTE DO ESTADO DO CEARÁ. 1992. Zoneamento ambiental da APA da serra de Baturité: diagnósticos e diretrizes, SEMACE, Fortaleza, 109 p.

SouZA MJN. 1997. Geomorfologia. In: IPLANCE (Eds), Atlas do Ceará, IPLANCE, Fortaleza, p. 18-19.

Souza VC, CORTopassi-Laurino M, Simão-Bianchini R, Pirani JR, Azoubel ML, Guibu LS and Giannini TC. 1994. Plantas apícolas de São Paulo e arredores. In: PIRANI JR AND CORTOPASSI-LAURINO M (Eds), Flores e abelhas em São Paulo, FAPESP, São Paulo, p. 43-179.

SUDENE - SUPERINTENDÊNCIA DO DESENVOLVIMENTO DO NoRdeste. 1982. Climatologia e balanço hídrico. Ceará. Dados pluviométricos. Temperaturas do Ceará estimadas por regressão múltipla: altitude, latitude e distância do mar, Projeto de Delimitação e Regionalização do Brasil Semiárido, Fortaleza, $30 \mathrm{p}$.

TAlorA DC AND Morellato LPC. 2000. Fenologia de espécies arbóreas em floresta de planície litorânea do sudeste do Brasil. Rev Bras Bot 23(1): 13-26.

UFC/FUNCEME - UNIVERSIDADE FEDERAL DO CEARÁ/ FundaÇão CeArense de Meteorologia. 1994. Geossistemas e potencialidade dos recursos naturais: serra de Baturité e áreas sertanejas periféricas (Ceará), FUNCEME, Fortaleza, $110 \mathrm{p}$.

VELOSO HP, RANGEL-FILHO ALR AND LIMA JCA. 1991. Classificação da vegetação brasileira, adaptada a um sistema universal, IBGE, Rio de Janeiro, 124 p.

VIANA BF AND KLEINERT AMP. 2006. Structure of bee-flower in the coastal sand dune of Abaeté, northeastern Brazil. Rev Bras Entomol 50(1): 53-63.

VIANA BF, KLEINERT AMP AND IMPERATRIZ-FONSECA VL. 1997. Abundance and flower visits of bees in cerrado of Bahia, tropical Brazil. Stud Neotrop Fauna and Environ 32(4): 212-219.

ViAnA BF, Silva FO AND KleINERT AMP. 2006. A flora apícola de uma área restrita de dunas litorâneas, Abaeté, Salvador, Bahia. Rev Bras Bot 29(1): 13-25. 
VIANA VM AND PINHEIRO AFV. 1998. Conservação da biodiversidade em fragmentos florestais, Série Téc. IPEF 12(32): 25-42.

Viana VM, TABAnez AJA AND Martinez JLA. 1992. Restauração e manejo de fragmentos florestais. In: Anais do II Congresso Nacional sobre Essências Nativas Conservação da biodiversidade, Instituto Florestal, São Paulo, p. 400-406.

WhitTAKeR RH. 1975. Communities and ecosystems, CollierMacmillan Ltda., New York, 385 p.
WiLMS W, IMPERATRIZ-FONSECA VL AND ENGELS W. 1996. Resource partitioning between highly eusocial bees and possible impact of the introduced africanized honey bee on native stingless bees in the brazilian atlantic rainforest, Stud Neotrop Fauna Environ 31(3/4): 137-151.

W3TROPICOS - VAST SPECIMEN DATA BASE. 2010. Missouri Botanical Garden, Saint Louis. (Available at: <http:// mobot.mobot.org/W3T/Search/vast.html.>).

ZAR JH. 1984. Biostatistical analysis, Prentice-Hall, New Jersey, $718 \mathrm{p}$. 
